\title{
CODE-SWITCHING IN THE ENGLISH TEACHING TO NON-ENGLISH DEPARTMENT STUDENTS
}

\author{
Yusuf Al Arief \\ Lambung Mangkurat University \\ yusufalarief@ulm.acid \\ Siti Haniifah Husnul Khotimah \\ Lambung Mangkurat University \\ hsitihaniifah@gmail.com
}

\begin{abstract}
Code-switching is a phenomenon studied in sociolinguistics. It exists in multilingual societies like in Indonesia, where people use more than one language to communicate including in classroom interaction, especially in the process of teaching English as a foreign language. This research aimed to find out the types and the functions of codeswitching used by English lecturers in teaching English to Non-English Department Students at FKIP of Lambung Mangkurat University in the Academic Year of 2017/2018. This research was conducted through the descriptive-qualitative method. The subjects were the lecturers of English class for Non-English Department Students or Mata Kuliah Dasar Umum (MKDU) Bahasa Inggris Class. The researchers used observations and confirmed the results from the interviews. The data were analyzed by data reduction, data display, and conclusion drawing or verification. The research result indicated that in the process of teaching English, the lecturers sometimes switched their languages: English, Bahasa Indonesia, Banjarase, and Arabic. There were three types of code-switching used by the lecturers which were tag-switching, intrasentential-switching, and intersentential switching. While for the function, there were three functions of code-switching used by the lecturers which were topic-switch, affective-function, and repetitive function. In conclusion, the lecturers switched their languages in some types and for various functions depending on the situation of their teaching activity and students' need.
\end{abstract}

Keywords: Code-switching, tag-switching, intersentential-switching, intrasententialswitching, topic-switch, affective-function, and repetitive function

\section{INTRODUCTION}

Language is the means people use to convey their ideas from one to another in a society. One of the language phenomena in this world is codeswitching. Code-switching is the changing process of one language to other language varieties within a single conversation or utterance (Wardaugh, 2006:96). Studies show that people switch their language in order to hold the topic of the person they may be speaking to. Code-switching can be used by bilingual and multilingual lecturers for many functions based on their proficiency levels, needs, and interests, for instance in teaching English for the students who learn English, not as their primary subject or Non-English Department Students (Khaerunnisa, 2016:14). 
In English Language Teaching (ELT) of the students in this class, it needs special attention since the students did not learn English regularly like English Department students. Therefore, the way the lecturers use classroom language is different as well because English is not their primary subjects. Then, sometimes the lecturer uses code-switching for example when she has to make students understand the materials or their instructions.

The phenomenon of code-switching which usually happened in English class of Non-English Department students class is sometimes categorized as natural. It is because the lecturers are not native speakers of English and their students do not only focus on English, or English is a specific major for the students. Code-switching is used by the lecturers in the classroom to support student's learning success. According to Norrish (1997:1), the lecturers may code switch in the level of English, whether in the explanation and the material in the textbook that is difficult to understand. Code-switching is a good tool to build an understanding between the lecturer and the students so that the class will be interactive. However, the lecturers must still use wisely their code-switching so that the goal of English language teaching still can be reached since the students of Non-English Department students are offered only 2 credits in a semester for learning English. For example, they should know what kind or type of their codeswitching and for what or function they code-switched in the classroom interaction, especially in the teaching process.

Generally, there are 3 types of code-switching that proposed by Wei $\mathrm{Li}$ (2000:19). Those are tag-switching where CS happened in the form of a tag or short phrase, intersentential-switching where CS happened between sentence barriers and intrasentential-switching where CS happens inside a sentence. For the functions of code-switching, Mattson and Burenhult (1999:3) provided three functions of code-switching in classroom interaction. The first one called a topicswitch function. In a classroom perspective, related to this function, the lecturer alters his/her language according to the topic that he or she talks about.

The second is affective function were usually served for expression of emotions (Mattson \& Burenhult, 1999:61). In this function, for instance, codeswitching is used by the lecturer in order to adequate solidarity, more deep relations, and show her status as a good lecturer to the students. Besides, the lecturer may speak of the contribution of code-switching for conceiving a supportive language envi-ronment in the classroom. Third, a repetitive function where $\mathrm{CS}$ is used by the lecturer to stress the meaning which has been said before by the speaker.

This research aimed to find out what types and functions of codeswitching used by the lecturers in the process of English teaching to Non-English Department Students. Some previous studies provided some findings related to code-switching. The first study is entitled The Use of Code-Switching by English Teachers in Foreign Language Classroom : A Descriptive Study at SMAN 1 Pangsid which comes from Ulfah (2016) which found that there were three types of code-switching used by the English teachers in the classroom. They were intersentential code-switching, intra-sentential code-switching, and tag switching. The 
functions commonly used by the teacher are for a topic switch, effective function, and repetitive function.

Next study is from Yleyinen (2004) entitled The Functions of CodeSwitching in EFL Classroom Discourse found that code-switching in EFL classroom is employed for varied reasons, those functions being social, discourse, and pedagogical. Additionally, Teachers' Code-Switching in the ESP Classroom in China comes from Shujing (2013) indicated that CS is extensively used by teachers of ESP class and that the guidance of the language switch and the capacity of teacher talk in English advise that the base language for ESP teaching is still English, and a code-switching is a necessary tool for teachers due to a number of pedagogical deliberations and sociolinguistic factors in ESP lessons including students who lack proficiency. Then, the differences of this research with the previous studies above are conducted in English Class of Non-English Departement students classrooms at the university level. Also, the main focus in this research is the use of code-switching by English lecturers that consists of types and functions of code-switching in English teaching.

\section{RESEARCH METHODS}

The research design used in this study was descriptive qualitative research. As the main purpose of this study to investigate the use of code-switching by the lecturers in teaching English to Non-English Department students from the lecturer's utterance in the classroom that consisted of types and function then described it. The population of this research was lecturers who teach English for Non-English Department Students. In this research, the researchers used convenience-sampling. According to Dornyei (2007:99), Convenience sampling is a sampling where representatives of the target population meet convinced practical criteria, such as easy accessibility, geographical closeness, an opportunity at a given time, or the eagerness to participate are included for the purpose of the research. In choosing the sampling, at first, the researchers made a list of the lecturers whose teaching for Non-English Department students at FKIP of Lambung Mangkurat University. In the English Department, there were eight lecturers who teach English for Non-English Department students. Then the researchers asked and confirmed to the lecturers for their convenience in this study. The samplings in this research were three English lecturers who teach English for Non-English Department Students. Those three lecturers were from three different Mata Kuliah Dasar Umum (MKDU) of Non-English Department class which are from Biology \& Mathematics major, Technology of Education, and Bahasa Indonesia at Lambung Mangkurat University Banjarmasin. There were some instruments used in this study. The first instrument was an observation sheet. The second instrument was also used in taking the data during the observation; it was called video-recorder. Besides, the researchers used taprecorder and interview guideline in taking the data for the interview. For the validity of the observation sheet, content-related-evidence validity and expert judgment were used by the researchers in this research.

For the first step of data collection, the data were collected by using observation in the English Classes of Non-English Department Students or Mata 
Kuliah Dasar Umum (MKDU) Bahasa Inggris Class where the majors were from Biology, Mathematics, Bahasa Indonesia, and Technology of Education to find appropriate information for obtaining the objectives of the study. By using a video recorder, the researchers recorded the conversation or the activity between the lecturer and students in the classroom as the documentation to make the process of transcribing the data easier. To get the saturated data, the observation was done in two times in three classrooms by observing the utterance used by the lecturers during the English teaching process in MKDU English class. The category's theoretical saturation is the criterion for judging when to stop the observation in qualitative research. According to Glaser and Strauss (1992:61), saturation means that no additional data are being found whereby the sociologist can develop properties of the category. As the researchers found similar instances over and over again, the researchers became empirically confident that a category was saturated. Next, the researchers wrote the transcript from the video record to make the analyzing proses easier, and it contains the certain forms of codeswitching used by the lecturer. After that, the researchers analyzed the data based on the theory about the types of code switching by Li Wei and theory of the function of code-switching by Mattson and Burenhult.

Triangulation of time and method were used in this research. After doing two observations for each lecturer in three different English or Mata Kuliah Dasar Umum (MKDU), Bahasa Inggris Class of Non-English Department Students, the researchers also did an interview to confirm and reinforce the observation result for each lecturer. The researchers as an interviewer asked some close-ended questions about the use of code-switching based on the observation result.

In analyzing the data, the researchers did 3 steps in analyzing the data for qualitative research based on the Miles and Haberman theory. According to Miles and Huberman (1994:12), there are three major phases of data analysis: data reduction by using the coding technique, data display, and conclusion drawing or verification.

\section{RESULT OF THE RESEARCH}

\section{Types of Code-Switching Used by the English Lecturers in Teaching Non- English Department Students}

\section{a. Pre-Activity}

Pre-activity is the first activity of teaching. It is the planning phase of the teaching activity. According to Kumar (2012:12), good preparation of plan makes a teacher's task will be run smoothly, functionally, and successfully. In preactivity, the researchers found that the lecturers did some activities such as reviewing the previous lesson, giving instruction for the lesson, and chalking out the details of their journey which they want to take in the classroom along with their students.

From the three lecturers, it was found that they used code-switching for 45 times where all the types of code-switching used by them in pre-activity of their teaching process. In pre-activity, the lecturers mostly used an intersententialswitching type of code-switching or code-switching which happened between 
sentence boundaries. At first, the lecturers spoke in English, then switch their language on the next sentence by using Bahasa Indonesia or Arabic phase when they said salam. Shujing $(2013: 20)$ stated that intersentential-switching type or also known as inter-unit code-switching occurring between units or between turns where usually the lecturers tried to use the target language first for their first sentence, then if the students seem confused with the material or instructions, they switch their language to the language that easier understood by the students in the next sentence.

From the confirmation in the interview, the lecturers used this type of code-switching in pre-activity for three aims. First, it could help the lecturers in giving and explaining the information and instruction in starting the lesson. Thus the materials or instructions were expected to become easier to be understood by the students, and the students understand about what they must do first. Secondly, it could be observed that the lecturers' effort to get respond from the students about the message, information, question about the previous meeting, and instruction which had been explained. Thirdly, the lecturers used this type of code-switching to lead the students to be the focus and assemble the attention of their students.

It was in line with Ulfah (2016) which revealed that the intersententialswitching used by the teachers in English classrooms mostly for delivering the instructions or the message that important for students to be understood. In this teaching phase, the lecturers mostly used this type of code-switching in saying salam where we know that Arabic phase is commonly used in Indonesia, then delivering the instructions and asking the students about what they have prepared before starting the lesson for the students. It is better to deliver the fully one language instruction so that the students would not confuse. The examples of intersentential-switching can be seen in (1), (2) and (3) below:

(1) Lecturer (S1): U4PRIM1: "Have you count? The correct answers? Berapa jumlah benarnya? Sudah dihitung?" (Have you count? The correct answers? How many the correct answer?) Have you counted?) and

(2) Lecturer (S2): U03PR1S2: "How many ..... you have learned? Berapa?" (How many?).

Pre-activity is important for the teacher or lecturer to know how far students' memory about the previous lesson. According to Keterampilan Dasar Mengajar (2017:77), sebaiknya dalam memberikan review mengenai pelajaran sebelumnya dalam bentuk kalimat lengkap dan jelas sehingga siswa mampu mengikuti dan memahami dengan mudah apa yang disampaikan oleh guru. (It is better if when the teacher or lecturer is reviewing about the previous lesson, he/she should explain in a complete and clear sentence so that the students can follow and understand easily about the topic).

The result was followed by tag-switching where the lecturers used it to make their interjection and clarification be easier for the students. Furthermore, the lecturers also used intrasentential-switching to make students more comprehensible with their information, for example when they review the 
previous lesson. The example of the use of tag-switching can be seen in the examples below:

(1) Lecturer (S2) U03PR2S2: I need to check, ya (yes)?

(2) Lecturer (S3) U01PR2S3: Ya, (Ya...) we are going to finish our lesson today because this is the last meeting, ya (yes).

The result above was in line with Murtaflah (2017:78) where the teacher used tag-switching to give interjections by using Bahasa Indonesia filler such as nah, yah, jadi, tapi, hah. This type of code-switching means to put a tag in one language to an utterance that is differently in another language (Wei, 2013:24). The lecturers used intrasentential-switching to make students more comprehensible with their information, for example when they review the previous lesson. The examples can be seen below:

(3) Lecturer (S2) U02PR1S1: Assalamualaikum semuanya. Umm..well, last time, do you remember what we learn ? The materi (material)? Do you remember what we learn in last meeting?

(4) Lecturer (S3) U13PR1S2: Soalnya kalau kalian sudah masuk ke dalam area compound sentence atau kalimat majemuk atau complex sentence kalian bicara tentang klau...? (It is because if we have talked about a compound sentence or complex sentence, you will talk about clau...?).

\section{b. While-Activity}

From the findings of three lecturers, it was found that the total number of code-switching which happened in while-activity were 991 times where all type of code-switching used by the three subjects in while-activity of their teaching process. From the observation, it was found that the most type of code-switching used by the lecturers for while-activity was intrasentential-switching where it was used by the lecturers for 474 times, followed by intersentential-switching for 300 times, and tag-switching for 217 times.

Based on the interview, the lecturers mostly used intrasentential-switching for their while-activity because while-activity was longer than the other activity and in this activity, the lecturer explains the material. In this case, they used it to explain the material which is related to grammar instruction so that the material will be easier understood by the students.

The purpose of intrasentential-switching type or code-switching within a sentence (Wei, L., 2013:23) was to help the students understand the meaning of difficult English words in giving an explanation of the particular topic.

In this case, the lecturers started their sentence in English, they switched it within their sentence into Bahasa Indonesia then switch it back again to English when it needed. It also supported with the result of Ulfah (2016) where she found that the factor using intrasentential- switching was surely observed for the sake of the contents to those words which were being discussed or connected to the topic which was being heightened. The examples of intrasentential-switching can be seen below:

(1) Lecturer (S1): U68W1S1: It must be I forgot, karena sudah lama..ee..karena sudah lupa ya, I forgot. (It must be I forgot because it was a long time..ee because I forgot yes, I forgot). 


\section{(2)Lecturer (S2)}

U84W1S2: Okay done, yang kedua Nabila sama dengan subject, don't want to drink sama dengan verb, okay this is? (Okay done, the second Nabila is the same as the subject, don't want to drink is sama with the verb, okay this is?)

\section{(3) Lecturer (S3)}

U25W2S3: Iya, karena yang pertama its group definite tertentu ya, a boy and a girl, but then in the second sentence kita sudah tau boy nya yang mana dan girlnya yang mana jadi kita gunakan the. (Yes, it is because the first one is certain definite group yes, a boy and a girl, but then in the second sentence we have known the boy and the girl so that we use the).

Besides using intrasentential-switching in the form of explanation, the lecturer also used this type when they delivered the message. When the lecturer taught the students in while-activity, sometimes the students were busy with themselves.

Therefore, the lecturer gave massage or clarification whether they understand or not about what was being taught. To make the message be easier understood by the students, the lecturer switched her language within a sentence immediately, especially, when she saw their students seem confused. In addition, the lecturers also used code-switching when he wanted to say a message to the students.

In while activity, the lecturer used intersentential-switching for repeating the explanation while tag-switching was used for giving interjections and clarifying the students about the material which has been taught. It can be seen in the example below:

(1) U174W2S3: It was rainy, and it was very cold. Sedang turun hujan, jadi harus pakai makna kalimat sesuaikan yang mana yang sedang. (It is raining now, so we must use sentence meaning which is appropriate).

The example number one showed that the lecturer used English in her first sentence, then in the next sentence, she switched it into Bahasa Indonesia. She tried to make students really understand the meaning of her sentence. Besides giving the example of intersentential-switching, the researchers also gave the example of a tag-switching type that can be seen below:

(1). Lecturer (S1) U101W2S1: President, ya (yes) ?

\section{c. Post-Activity}

Post-activity is the last activity in the teaching process. In this part, the interaction between the lecturers and the students will be less than while-activity since the time for this part was shorter that while-activity. Although it is the last activity, the lecturers should still motivate the students so that they still pay attention well and feel comfortable (Erwin, C., 2016:4).

From the three lecturers, it was found that the total number of codeswitching which happened in post-activity were 60 times. The most type of codeswitching which used by the lecturers for post-activity was intrasententialswitching where it was used for 51 times, followed by both intersententialswitching for 21 times and tag-switching for 14 times. Intrasentential-switching 
was mostly used by the lecturers in reviewing their lesson, so it can make students more comprehensible with the review. The examples of the use of intrasententialswitching type can be seen below:

(1) Lecturer (S1) U146W1S1: They are late to come to the class, and they have some many reasons like kesiangan Miss, ban bocor Miss, ini ini..dan sebagainya. (They are late to come to the class, and they have some many reasons like, wake up lately Miss, leaking tire Miss, because it is..and so on).

(2) Lecturer (S2) U179PO2S2: Apa yang dimaksud dengan simple sentence, combining sentence, complex sentence, run-on sentence, dan...? (What is meant by simple sentence, combining sentence, complex sentence, run-on sentence, and..).

Beside using intrasentential type in the form of review, the lecturers also used this type in post-activity when they said their message for their students. It can be seen on the example below:

(1) Lecturer (S2) U188PO2S2: Kalau kalian semua penasaran, bagaimana cara bapak membuat soal ya, barangkali kalian bisa mempelajari pelajaran noun misalnya berarti kalian mencari noun exercises cari dan terus pelajari disitu. (If you all are curious with it, how do I make the test, you may learn noun material, for example, you may search noun exercises, search and then learn it there).

Additionally, the lecturer also used intrasentential-switching type. It was showed on:

(2) Lecturer (S3) U158W1S3: Okay, ya...good. Okee. Do you have questions for today's material?

\section{Functions of Code-Switching Used by the English Lecturers in Teaching Non-English Department Students}

a. Pre-Activity

In pre-activity, the researchers found that the lecturers did some activities such as reviewing the previous lesson, giving instruction for the lesson, and chalking out the details of their teaching journey which they want to take in the classroom with their students.

From the three lecturers, it was found that the total number of codeswitching which happened in pre-activity were 45 times for various functions such as for topic-switch, for affective function, and repetitive function.

The researchers found out that in pre-activity, the lecturers mostly used code-switching for affective function or the function of code-switching which was related to emotional understanding (Mattson and Burenhult, 1999:9). This function was strongly related to a comfortable situation which can be built together by the lecturers and the students. The lecturer switched another language besides English to make the students feel calm that the lecturer still understands they are Non-English Department students. 
In addition, according to Kumar (2012:4), teaching is a social complex phenomenon. It is very important for creating good interaction between the lecturers and the students, especially in starting the lesson. The code-switching for affective function in pre-activity can be seen in the following examples:

\section{(1) Lecturer (S1)}

U01PR1S1: Assalamualaikum (peace be upon you) semuanya. Umm..well, last time, do you remember what we learn ? The materi? Do you remember what we learn in last meeting?

It is important to create a comforting atmosphere with the students in starting the lesson. According to Keterampilan Dasar Mengajar (2017:77), dalam membuka pelajaran, hendaknya seorang guru mampu memahami situasi dan kondisi di kelas sehingga mampu menciptakan suasana yang nyaman di kelas (In opening the lesson, a teacher should understand the situation and condition of the whole of class so he/she can build comfortable atmosphere easily). In addition, the researcherss and scholars saw codeswitching as facilitating of relaxing and warm atmosphere in the class also build comprehension of the material easier (Dykhanova, 2015:14).

(2) Lecturer (S2) U02PR1S2: Last week, I didn't come here because HarDikNas ya (yes)?

U04PR1S2: Actually you should have a test, tapi karena, bapak tu biasanya memahami kalau misalnya kita tidak masuk, salah satu karakter dari kalian adalah tidak siap jadi nilainya mungkin nilainya akan down grade, yaah ? (Actually, you should have a test, but because, I usually understand if we did not have any class before, one of your characters is you are not ready so that maybe your score will be in down grade, right?)

(3) Lecturer (S3) U03PR1S3: Try to understand the text with your group, and after that, we discuss the text ya (yes).

Beside switching for affective function, in pre-activity, the lecturers also switched their language for other functions such as for topic-switch and repetitive function. The example of topic-switch function can be seen on the following example:

(1) Lecturer (S2) U12PR1S2: One, that is about sentence. Pernah belajar sentence belum di awal-awal meeting?

The example of repetitive function can be seen below:

(2) Lecturer (S1) U4PR1S1: Have you count? The correct answers? Berapa jumlah benarnya? Sudah dihitung? (Have you counted? The correct answers? How many totals correct? Have you counted?)

From those examples, the lecturer used code-switching to repeat her question and her instruction then the students understand what she meant. It is important to make the students understand the information or instruction at the beginning of the lesson so that misinterpretation would not happen. The lecturers used code-switching based on the situation it needed. In using codeswitching for affective function, code-switching mostly used for interpersonal 
or social purposes of interaction between the lecturers and the students (Then and Ting, 2011:9).

\section{b. While-Activity}

While-activity is the stage of actual teaching where the lecturers usually talk about the main topics. According to Kumar (2012:13), while-activity or reciprocal phase of teaching is connected with the implementation of what has been prepared and planned in the previous stage or pre-activity. At this stage, the lecturers make an explanation to the students, ask questions listens to student's responses and guide the students.

From the three lecturers, it was found that the total number of codeswitching which happened in while-activity were 991 times where the lecturers used code-switching mostly for topic-switch where it used for 435 times, followed by switching for affective-function where it used for 374 times, and for repetitive function for 201 times.

The lecturer used code-switching for topic-switch mostly when they tried to explain a topic or information which was quite difficult such as grammar to understand by the students. This is in line with the theory of Cole (1998:72), sometimes in the situations where grammar is instructed, the teacher shifts his/her language to the mother tongue of his or her students in dealing with particular grammar points that are being taught at that moments. It is expected when they switched into the language mastered by the students, and their students will really understand the topic. Therefore, it may be proposed that an association from known (native language) to unknown (in this context is new foreign language content) is built to deliver to the new content which enables clearness (Mattson and Burenhult, 1999:33).

Some following examples on the use of code-switching for topic-switch were shown below:

\section{(1) Lecturer (S1)}

U68W2S1: It must be I forgot, karena sudah lama..ee..karena sudah lupa ya, I forgot. (It must be I forgot because it was a long time..ee because I forgot yes, I forgot).

(2) Lecturer (S2)

U06W2S2: Conjunction yang digunakan dalam combining sentence? (What kind of conjuction is used in combining sentence?)

\section{(3) Lecturer (S3)}

U30W2S3: Mike is a shoulder in the ARMY, betulkah itu pakai the? (Mike is a shoulder in the ARMY, is it true to use the?).

Beside using code-switching for topic-switch, the lecturers also switched their language for affective and repetitive function. It can be seen in the following examples

(4) Lecturer (S3) U14W1S3: We need to embrace the new curriculum misalnya ya (yes).

U20W1S3: Yes. Kita artikan bersama perlukah? (Do we need to check it together?). 
Last, the lecturers also switched language for repetitive function, for example when the topic related to the new vocabulary that was showed on the example below:

(5) Lecturer (S1) U73W2S1: Ya, oh okay, interruption. Interupsi (Interruption). U78W2S1: At the end yes? Biasanya di akhir diskusi, kalian. (Usually at the end of a discussion, you guys..).

Besides, she also code-switched to make sure something to the students which can be seen in the example below:

(6) Lecturer (S1) U85W2S1 : Another one I have..when I disagree here, can you see the word, the sentences here ? Bisa lihat ya?. (Can you see it, right?)

In while-activity, all functions of code-switching that are proposed by Mattson and Burenhult (1999:33) were found, and the lecturers mostly use codeswitching in this part for topic-switch function. It was because, in while-activity, the lecturers mostly explained the material. In addition, the lecturers also used code-switching sometimes for repeating the materials which have been explained and tried always to create comfortable atmosphere for the students.

\section{c. Post-Activity}

In post activity, it was found that the total number of code-switching used by the three lecturers were 60 times. The lecturers mostly used code-switching in post-activity for affective function, repetitive function, and topic-switch. According to Mattson and Burenhult (1999:3), sometimes teachers or lecturers use code-switching to express their emotions, besides it also contributed the ability of teachers and lecturer to create supportive language environment in language learning classrooms.

It was because the role of the lecturers in the teaching activity especially in opening and closing part could give impact to student's emotional. It is better if the lecturers could start the lesson with the comfortable environment so that the students felt motivated and excited in learning English and in the closing the lesson, they should make the students still have high spirit in learning so that the material can easily to understand. The examples of the use of code-switching for affective function can be seen below:

Lecturer (S2)

U176PO2S2: Bapak sebenernya belum yakin penuh pemahaman kalian tentang subject verb-agreement karena ada berapa rumus yang kita hafal? (I am not really sure about your understanding of subject-verb agreement because there are some formulas that should be remembered by us?).

\section{Lecturer (S3)}

U181PO2S3: Iyaa (Yes), when you apply for a job at a company, you need to make a CV or Curriculum Vitae.

Beside using code-switching for affective function, the lecturers also used code-switching for repetitive and topic-switch function. They used code-switching 
for repetitive function when they tried to repeat the instruction or information to their students so that students really understand. It was shown in the example below:

(1) Lecturer (S1): U154W1S1 Submit the video on the final test. Kumpul (submit) the video on the final test.

\section{Code-Switching in Teaching English to Non-English Department Students (Mathematics and Biology, Bahasa Indonesia, and Technology of Education Students)}

In Lambung Mangkurat University, English is an important subject. It is not only learned by the students in the English Department major, but it is also learned by Non-English Department students who are called as Mata Kuliah Dasar Umum (MKDU). This subject is provided by the university and students of Non-English Department must take the course in two credits for one semester. This is a general basic course so that the students did not learn English specifically like the students of English Department that is why teaching English to Non-English Departments students were different with teaching English to English Department students.

Since the students were not learning English as their major, the students also have different need and ability. Hence, the use of code-switching usually occurs during English language teaching, especially when studying English based on different backgrounds and reasons (Yusuf, 2009:7).

From the observation and interview with the lecturers of English for NonEnglish Departments students that were from Mathematics and Biology, Bahasa Indonesia, and Technology of Education class, the researchers found that sometimes the lecturer used code-switching in the process of teaching. The lecturers thought that they need to code-switched their languages mostly because students' lack of ability in English so that some of them preferred the lecturers to switched their language to Bahasa Indonesia. This was in line with Then and Thing (2016:8) where code-switching is used to bridge breaches in comprehension appearing from the students' lack of proficiency in language classes.

In addition, a previous study from Shujing (2013) pointed out that CS is broadly employed by ESP teachers, and that the guidance of the language switch and the capacity of teacher talk in English suggest that the base language for ESP teaching is still English, and a code-switching is a basic tool for teachers. It was due to a figure of pedagogical considerations and sociolinguistic factors in ESP teaching-learning process involving students who lack proficiency.

In the classroom, sometimes the lecturer found the students seemed they did not understand the point that she or he was talking about so that the lecturer thought that in that time they needed to help the students in understanding the point by switching their language into Bahasa Indonesia.

However, after using Bahasa Indonesia, she switched back her language into English because it was an English class. It was confirmed by the interview with the lecturers that the use of code-switching, in this case, was used by them in 
making a clarification and making the students understand more about what the lecturer was saying about. This was in line with Heller (2007:150) whose states code-switching that happens in the classroom is often observed as a strategy for use in communication and interaction that used in terms of syntactic applications, exclusions switching topics, elaborations or comments, acceptance, and clarifications.

When the lecturer explained a particular topic, which was quite difficult, for example when the topic was related with grammar in English, then students seemed confused and when they asked the students, they could not answer properly then they code-switched their language to make the explanation easier and clearer for the students. According to Norrish (1997:1), lecturers' codeswitching happened at the English level, whether in the explanation, task or in the textbook that is quite difficult to understand. If the lecturers saw the sign of getting confused from students' expression with what the lecturers were talking about, then they code-switched their language.

Another example such as in starting the lesson, sometimes the lecturer used English, then she or he switched to Bahasa Indonesia when she or he found some students that did not seem to understand the instructions or they did not reply her greeting in English.

Code-switching that happened in English class for Non-English Department students were categorized natural since they do not learn English as their major subject. The lecturers code-switched their language in classroom interaction to make them easier to understand what they meant in the teaching process. According to Bista (2010:2), ESL teachers, linguistics, and researcherss believe that CS is not doubt a blockage or failure in the process of learning language, it may be beneficial if it is used wisely in teaching language to the students.

Code-switching is used by the lecturers in the classroom to support student's learning success. In this case above, code-switching was a tool to manage and facilitate interaction in the teaching process so that the student could learn English well (Fachriyah, 2017:149).

However, not all of Non-English Department students lack ability in English and did not interest when the lecturer spoke fully in English. In three classrooms of Non-English Departments students whether in Biology and Mathematics subjects, Bahasa Indonesia, and Technology of Education, codeswitching use depends on the situation of teaching process which strongly related with students' ability in English.

The lecturer believed all students like to learn English, but there were some students who just not confident to learn English. Those students would prefer their lecturer to speak Bahasa Indonesia rather than English. It was common if the students tell the lecturer that "sebaiknya dosen menggunakan Bahasa Indonesia" (The lecturer should use Bahasa Indonesia). On the other side, those students who understand, they would prefer their lecturer to use English in their classroom. To make it balance, how the lecturers used code-switching depends on the situation wisely. 


\section{CONCLUSION}

Based on the findings and the discussion, it can be concluded as follows.

1. Sometimes the lecturers switched their main language of interaction which means lecturers used code-switching in several types and for various functions. Three types of code-switching that proposed by Li Wei that consists of tag-switching, intrasentential-switching, and intersentential-switching were used by the lecturers depending on the teaching phases.

2. The use of code-switching in the teaching process was intentional. The functions of code-switching were topic-switch, affective function, and repetitive function.

\section{REFERENCES}

Bokamba, E. 1989. Are there syntactic Constaints on code-mixing ? World Englishes. 8 (3). Africa: Illonis Lingusitics Publisher

Brown, H. Douglas. 2003. Language Assesssment: Principle and Classroom Practice.New Jersey: Addison Wesley Longman Inc.

Castello, D. 2015. First Language Acquisition and Classroom Language Learning Similarities and Differences. Boston :University of Birmingham

Creswell, J. 2012. Educational Research: Planning, Conduction, and Evaluation Quantitative and Qualitative Research $4^{\text {th }}$ ed. Boston:Pearson Publisher.

Dornyei, Z. 2007. Research Methods in Applied Linguistics. New York: Oxford University Press.

Dykhanova, A. 2015. Functions of Code-Switching and Attitudes towards them: A Case Study of Eastern Mediteranian University: Dogu Ak-nezis University Publisher.

Erwin, S. 2016. 10 Ways Teachers Can Create a Positive Learning Environment.California: Free Spirit Publishing Ltd.

Fachriyah, 2017. The Functions of Code-Switching in an English Language Class. Banten:Serang Raya University. ISSN : 2755-2794.

Fifi.2015. An Analysis on the Use of Code-Switching by Music Program Presenters in MTV VJs and BVoice Show from Binus University, Jakarta.

Flyman, A. 1997. Communication strategies in French as a foreign language. Lund : Lund University Publisher. 
Flyman, A and Burenhult, N. 1999. Code-switching in second language teaching of French. Lund : Lund University Publisher.

Glaser BG, Strauss AL. 1992. The Discovery of Gorunded Theory : Strategies for Qualitative Research. Chicago :Aldine

Hall. 2008. Classroom Interactions and Language Learning. Georgia: University of Georgia Publisher.

Heller, M. 2007. Bilingualism: A Social Approach. New York: Palgrave MacMillan.

Jack R. Fraenkel., et al. How to Design and Evaluate Research in Education the $8^{\text {th }}$ Edition. New York: McGraw-Hill, a business unit of The McGraw Hill Companies, Inc., 1221 Avenue of the Americas, New York, 10020.

James H. Mcmillan. 1996. Educational Research Fundamentals for the Consumer $^{\text {nd }}$ Edition. United States of America : HerperCollins Publisher.

Holmes, J. 2003. An Introduction to Sociolinguistics the $4^{\text {th }}$ Edition. New York:Rotledge Publisher.

Josiane F. Hamers and Michel H. A. Blanc. 2004. Bilinguality and Bilingualism Second edition. London: Cambridge University Press.

Kharenunnisa. 2016 An EFL Teacher's Code-Switching in a Young Learners' Class. Indonesian Journal of EFL and Linguistics. Vol. 1 No.201 EISSN : 2503-4197, pISSN: 2527-507

Kothari, C, R. 2004. Research Methodology: Methods and Techniques (2 ${ }^{\text {nd }}$ Revised Ed).Jaipur: New Age International Publisher.

Kumar, P. 2012. Advanced Methods of Teaching. Benguluru: Himalaya Publishing House.

Miles, M.B and A.M Huberman. 1994. Qualitative Data Analysis. Thousand Osks: Sage Publications

Mu'in, F \& Sirajuddin, K. 2006. An Introduction Material for Sociolingustic. Banjarmasin: PBS FKIP Universitas Lambung Mangkurat.

Mu'in, F., Dini, N.A., \& Rosyi, A. 2018. Language in Oral Productipn Perspectives. Banjarmasin:CV.Rasi Terbit.ISBN: 978-602-6644-48-0

Norrish, J. 1997. english or English ? Attitudes, Local Varieties and English language Teaching. TESL-EJ3, 1, 1-14. 
Poplack, S. 1980. Sometimes I'll Start a Sentence in Spanish Y TERMINO EN ESPANOL: Toward a Typology of Code-Switching. Ottawa: University of Ottawa.

Richards, Jack et al. 1992. Longman Dictionary of language teaching and applied Linguistics. Harlow:Essex.

Saldana.2013. The Coding Manual for Quali- tative Research. Thousand Oaks, California: SAGE Publications Ltd. ISBN 978-1-84787-548-8.

Setiyadi, Ag, Bambang. 2006. Metode Penelitian untuk Pengajaran Bahasa Asing Pendekatan Kuantitatif dan Kualitatif. Yogyakarta: Graha Ilmu.

Sugiyono. 2015. Metode Penelitian Pendidikan: Pendekatan Kuantitatif, Kualitatif dan R\&D. Bandung : Alfabeta Bandung Publisher.

Tej K. Bhatia, William C. Ritchie. 2012. The Handbook of Bilingualism and Multilingualism The $2^{\text {nd }}$ Edition. New York: Wiley Blackwell.

Then D.C, Ting S,Thie,. 2016. Researching Code-Switching in Teacher Language Society and Culture. Sarawak: Malaysia Language Society and Culture Paper Publisher. ISNN : 1327-174X

Tickoo M.L. 2009. Teaching and Learning, English. Hyderabad : Orient Black Swan.

TIM. 2017 Keterampilan Dasar Mengajar. Banjarmasin: Unit Micro Teaching dan Program Pengalaman Lapangan (UMTPPL) Universitas Lambung Mangkurat.

Tom Hutchinson \& Alan Waters. 1991. English for Spesific Purposes. New York: Cambridge University Press.

Ulfah, N, M. 2014. The Use of Code-Switching by English Teachers in Foreign Language Classroom. Makassar:Makassar Muhammadiyah University. Accessed on $26^{\text {th }} \quad$ February, 2018. From http://www.academia.edu/11450523/THE USE OF CODE SWITCHI NG_BY ENGLISH_TEACHER IN_FOREIGN_LANGUAGE_CLAS SROOM.

Van Dulm, O. 2015. Constraints on South African English-Afrikaans Intrasentential Code-Switching: A Minimalist Approach. South African: Stellenbosch Papers in Linguistics Plus 31, 63-90. 
Wardaugh, R. 2006. An Introduction to Sociolinguistics. New York: Blackwell Publishing Ltd.

Wei L, 2000. The Bilingualism Reader. London EC4P 4EE: Routledge 11 New Fetter Lane

Wu Shujing. 2013. Teachers' Code-Switching in the ESP Classroom in China. Studies in Sociology of Science Vol. 4, No. 4, 2013, pp. 1622.DOI:10.3968/j.sss.1923018420130404.2847. 